\title{
Research on the reason of Olympic internationalization success from the cross-cultural perspective
}

\begin{abstract}
Although the modern Olympics has a history of just over one hundred years, compared with ancient Olympics, the internationalization of the Olympics has shown great success both from the members of the organization, the scale of the Olympics and the worldwide Olympic-related activities, which depends on its cross-cultural features. Cross-cultural features are shown in 4 aspects: the organization and organization members, bidding and hosting, sports projects and ideological system. Which precisely are the reasons for the great success of the Olympics internationalization? This study found: 1) cross-cultural organization and management made Olympics lead the healthy development of world sports; 2)the cross-cultural ideological system made the Olympics have a broad national foundations; 3 )cross-cultural exchanges and exhibitions made various national cultures Respected and developed.
\end{abstract}

Keywords: culture-cross, olympics, internationalization
Volume I Issue 6 - 2017

\author{
Zhang Haijun, Guo Xiatao, Zhang Shangyan, \\ Zhang Haili \\ Department of Physical Education, The Hunan first Normal \\ University, China
}

\begin{abstract}
Correspondence: Zhang Haijun, Department of Physical Education, The Hunan first Normal University, China, Yuelu District, Changsha City, Hunan Province, Tel 8613975 I 64592.
\end{abstract} Email zhhj1488@sina.com

Received: November 22, 2017 | Published: December 28 2017
Abbreviations: IOC, international olympic committee; IFS, international sports federation; NOC, national olympic committee;

\section{Introduction}

The modern Olympics are not only the largest sports phenomenon to date in the history of human society, but also a great social culture phenomenon in the history of human civilization. ${ }^{1}$ A broad sense of Olympic culture is the sum of material and spiritual wealth created by the Olympics in practice. Material wealth, namely material culture, mainly refers to the transformation and development of human sports skills by Olympics, all kinds of equipments adopted by various venues and facilities, as well as cultural forms resulting from. Spiritual wealth, namely spiritual culture, mainly refers to the influence of Olympics on human's inner world and social behavior, and the related cultural and artistic activities. Which is also the narrow sense of Olympic culture ${ }^{2}$ ? Olympic culture is a multi-culture dominated by western culture, it is also a culture centered on education, and a culture taking sports as a carrier, and an advanced culture with great ideals and promotion. ${ }^{3}$

The Olympic culture connotation is very rich, mainly reflected in six aspects: harmonious development, unity and friendship, fair competition, focusing on participation, work hard, win glory for own country. Which reflects the human pursuit of truth, goodness and beauty, and is the precious wealth of human beings. ${ }^{4}$ Olympism is the core of the Olympic culture. The Olympic culture has promoted the social modernization of the whole world, driven the development of social economy and the progress of science and technology, and played a positive role in environmental protection and the green global plan. It also made the meaning of Olympics extend to a more Longitudinal and deeper level made it a multi-channel and multi-faceted way of economy, science and technology, culture communication. ${ }^{5}$ The great success of the internationalization of the modern Olympics is closely related to the cross-cultural features. Studying the cross-cultural features of the Olympics will further promote the enrichment and development of the Olympics, all ethnic cultures as well.

\section{Investigation in Olympics cross-culture}

\section{The cross-culture of organizations and members}

The successful internationalization of the Olympics is due primarily to the leading organization-IOC, the cross-cultural structure:

A. IOC started out as an international organization. The first Olympic conference, 20 representatives from 8 countries including France attended the meeting, The agreement form of the conference was Olympic Charter, the Universality of IOC in Olympic Charter was reflected in: first, the operation of the IOC faced to the world; second, the worldwide competition had unified technical standards; third, many countries with different political system, economic development and cultural background joined the Olympic family. ${ }^{6}$

B. The three pillars of IOC (IOC, NOC, IFS) and the leading bodies (the Executive Committee, 15 people) had extensive international representativeness. The Executive committee is democratically elected by secret ballot by representatives of IOC members at the plenary session. Representatives of IOC members were from NOC, IFS and the athletes' representatives.? The internationalization of the members was the foundation of IOC internationalization. Because of the rapid development of the Olympics, by 2012 London Olympics, the NOC has reached 204, which means that almost all the world's nations are the representatives of IOC.

\section{The cross-culture of bidding for and hosting olympics}

The bidding for and hosting Olympics are the best reflection of the Olympic cross- culture. From the second session the modern Olympic was hosted outside Greece (2004 returned to Athens for Centennial) that is related to the Olympic bidding procedure which was divided into four steps:

a. Each city's bidding are accept, publish regulations and submit the questionnaire; 
b. IOC Executive Committee confirm the candidacy, Candidate cities submit bidding reports;

c. IOC Evaluation committees investigate and evaluate bidding city;

d. Statement by the bidding city, the hosting city is determined.

These 4 steps reflect the openness and tolerance of IOC to various cultures. The first step of registration, as long as a member of the Olympic family, the city is eligible to sign up. In the second and third step, both the Executive Committees and the judges of the IOC come from different countries. Especially in the fourth step, the critical voting step, nearly 100 people participate in voting (2013 year, bided for 2020 Olympics, 96 people voted). These four steps can fully reflect the concept of democracy, impartiality, openness and inclusiveness. In fact, we can intuitively understand this point from the final choice of the host city.

From 1896 the first Olympics to 2016 Brazil Olympics, the Summer Olympics were held 31sessions, plus the 2020 Tokyo Olympics, the Olympics were held in the 5 continents of the world and different countries of political systems, economic systems and cultural background (Table 1), after the 2nd World War (globalization began) a total of 19 Olympics were held, in addition to Africa and Antarctica did not hosted Olympics due to the special geographical and social environment, other continents have hosted or will host it before 2020, including 8 sessions in Europe, 4 in Asia, 2 in Oceania, 4 in North America, 1 in South America .As far as the political system of the hosting country is concerned, there were 8 constitutional monarchy, 4 Parliament republicanism, 3 Presidential republicanism, 3 Federal republicanism, and 1 People's Congress system. In terms of the economic background of hosting countries, 15 developed countries, 2 undeveloped countries, and 2 developing countries. As far as the cultural background of the hosting countries is concerned, there were 12 western cultures, 4 East cultures, 1 Indian culture, 1 Slavic culture, and 1 Latin American culture.

Although the numbers of different political systems, cultural and economic background of the hosting countries were unbalanced, but we shall understand this unbalance from many aspects: First, it is necessary conditions that the hosting city has a good traffic and safe environment by regulations, which is objectively unbalanced between countries and regions. It is understandable that the hosting number of developed countries is far more than the developing countries, but we must be beware of making use of the developing issues to restrict Olympics hosting and participation of the developing countries; Second, some countries with special cultural background and political system are few, naturally, the opportunity to host is relatively small; Final, in the contemporary society of western hegemony, it is normal because that Olympics stay in the cradle of western culture more time than others, We cannot blame cross-culture non-existent. No doubt, as both are developing countries and different cultures, the Olympics hosting in China and Brazil has far-reaching practical significance, which indicates that developing countries are important members of the Olympics family, the internationalization of the Olympics is inseparable from the developing countries, the Olympic culture is becoming more and more brilliant because of the exchange and integration of Chinese culture and Latin American culture.

Table I List of cities held by the Olympic Games after World War II

\begin{tabular}{|c|c|c|c|c|c|c|c|}
\hline Sessions & $14^{\text {th }}$ & $15^{\text {th }}$ & $16^{\text {th }}$ & $17^{\text {th }}$ & $18^{\text {th }}$ & $19^{\text {th }}$ & $20^{\text {th }}$ \\
\hline Cities & London & Helsinki & Melbourne & Rome & Tokyo & Mexico & Munich \\
\hline Countries & Britain & Finland & Australia & Italy & Japan & Mexico & Germany \\
\hline continents & Europe & Europe & Oceania & Europe & Asia & North America & Europe \\
\hline Political & Constitutio nal & Parliament & Constitutio nal & Parliament & Constitutio nal & President & Parliament \\
\hline System & monarchy & republicanism & monarchy & republicanism & monarchy & republicanism & republicanism \\
\hline Economy & developed & Undeveloped & developed & developed & developed & developed & developed \\
\hline Culture & Western culture & Western culture & Western culture & Western culture & East culture & Indian culture & Western culture \\
\hline Sessions & $21^{\text {st }}$ & $22^{\text {nd }}$ & $23^{\text {rd }}$ & $24^{\text {th }}$ & $25^{\text {th }}$ & $26^{\text {th }}$ & \\
\hline Cities & Montreal & Moscow & Los Angeles & Seoul & Barcelona & Astra & \\
\hline Countries & Canada & Soviet & USA & South Korea & Spain & USA & \\
\hline Continents & North America & Europe & North America & Asia & Europe & North America & \\
\hline $\begin{array}{l}\text { Political } \\
\text { System }\end{array}$ & $\begin{array}{l}\text { Constitutional } \\
\text { monarchy }\end{array}$ & $\begin{array}{l}\text { Federal } \\
\text { republicanism }\end{array}$ & $\begin{array}{l}\text { Federal } \\
\text { republicanism }\end{array}$ & $\begin{array}{l}\text { President } \\
\text { republicanism }\end{array}$ & $\begin{array}{l}\text { Constitutional } \\
\text { monarchy }\end{array}$ & \multicolumn{2}{|c|}{ Federal republicanism } \\
\hline Economy & developed & developed & developed & developed & developed & \multicolumn{2}{|l|}{ developed } \\
\hline Culture & Western culture & Slavic culture & Western culture & East culture & Western culture & \multicolumn{2}{|l|}{ Western culture } \\
\hline Sessions & $27^{\text {th }}$ & $28^{\text {th }}$ & $29^{\text {th }}$ & $30^{\text {th }}$ & $\left.3\right|^{\text {st }}$ & \multicolumn{2}{|l|}{$32^{\text {nd }}$} \\
\hline Cities & Greater & Sydney & Athens & Beijing & London & \multicolumn{2}{|l|}{ Rio } \\
\hline Countries & Australia & Greece & China & Britain & Brazil & \multicolumn{2}{|l|}{ Japan } \\
\hline Continents & North America & Europe & Asia & Europe & South America & \multicolumn{2}{|l|}{ Asia } \\
\hline $\begin{array}{l}\text { Political } \\
\text { System }\end{array}$ & $\begin{array}{l}\text { Constitutional } \\
\text { monarchy }\end{array}$ & $\begin{array}{l}\text { Parliament } \\
\text { republicanism }\end{array}$ & $\begin{array}{l}\text { People's congress } \\
\text { system }\end{array}$ & $\begin{array}{l}\text { Constitutional } \\
\text { monarchy }\end{array}$ & $\begin{array}{l}\text { President } \\
\text { republicanism }\end{array}$ & \multicolumn{2}{|c|}{ Constitutional monarchy } \\
\hline Economy & developed & Undeveloped & developing & developed & developing & \multicolumn{2}{|l|}{ developed } \\
\hline Culture & Western culture & Western culture & East culture & Western culture & Latin American culture & \multicolumn{2}{|l|}{ East culture } \\
\hline
\end{tabular}




\section{The cross-culture of projects}

This paper analyzes the cross-culture of projects from two aspects both projects sources and projects national suitability. From projects sources:

A. Olympic projects include sports, disciplines and events, the sports are 36 from 12 countries and regions, three continents and many different cultures (Table 2);

B. According to the 2005 IOC agenda, sports set no more than 28 , no less than 15 .

Projects set by the hosting country, and decided by the IOC session that makes the appropriate adjustments to the sports, disciplines and events according to participation and attraction (the last three sessions change as follows (Table 3); In 2014 in the 127th IOC plenary session, 2020 Olympic agenda was passed, no restrictions for sports, events allowed for a maximum of 310 . Such reform actually opens more sports into the Olympics. ${ }^{8}$ The diversity of Olympic culture will be further developed. About projects national suitability: through the medals results of the last 7 Summer Olympics, the top three are mostly in the USA, China and Russia. But this three countries did not have an absolute advantages, other countries accounted for a large proportion of medals (Table 4) which showed that projects advantages in other countries were also prevalent (Table 5). There are a great relationship between projects advantages and each country or nation's culture, history, geography, race, etc, such as Brazil ${ }^{9}$ and Argentina's football ${ }^{10}$ are mostly related to their culture and history; French fencing, ${ }^{11}$ South Korea's Taekwondo and archery ${ }^{12-14}$ are related to their historical culture tradition; Australia, ${ }^{15}$ British $^{16}$ and Canada's sailing and geographical location have a natural relationship; China's advantages of weightlifting, table tennis, diving are related to history, culture and tradition. Projects national suitability can increase the participation of various countries and ethnic groups, while respect and allow the independent and free development of their respective cultures.

Table 2 Source countries for summer olympic games

\begin{tabular}{|c|c|c|c|c|c|c|c|c|}
\hline Sports & Trampoline & Beach volleyball & Softball & Track and field & Swimming & Gymnastics & Tennis & Rugby \\
\hline \multirow[t]{2}{*}{ Source Countries } & France & USA & USA & Greece & Britain & Greece & France & Britain \\
\hline & & & & Britain & & & & \\
\hline Sports & Football & Eurhythmics & Triathlon & Taekwondo & Archery & Table Tennis & Basketball & \\
\hline \multirow[t]{2}{*}{ Source Countries } & China & Germany & USA & Korean Peninsula & Britain & Britain & USA & \\
\hline & & Greece & & & & & & \\
\hline Sports & Rowing & Water Polo & Diving & Boxing & Bicycle & Badminton & Volleyball & \\
\hline Source Countries & Britain & Britain & Sweden & Britain & France & Britain & USA & \\
\hline Sports & Equestrian & Synchronized Swimming & Sailboard & Weightlifting & Canoeing & $\begin{array}{l}\text { Modern } \\
\text { Pentathlon }\end{array}$ & Shooting & \\
\hline Source Countries & Britain & Canada & Hawaii & Britain & Canada & France & USA & \\
\hline Sports & handball & hockey & Sailboat & Baseball & Judo & Wrestling & Golf & \\
\hline \multirow[t]{2}{*}{ Source Countries } & Germany & Britain & Netherlands & Britain & Japan & Greece & Scotland & \\
\hline & & & & & & China & & \\
\hline
\end{tabular}

Table 3 Number Changes of projects in the last three Olympic Games

\begin{tabular}{lllll}
\hline Sessions & Sports number & Disciplines number & Events number & Projects changes \\
\hline Beijing olympic games & 28 & 38 & 302 & \\
London olympic games & 26 & 36 & 302 & Baseball, Softball out \\
Rio olympic games & 28 & 38 & 306 & Golf, 7-man Rugby in
\end{tabular}

Table 4 The top three medals in last 7 summer olympic games compared with others

\begin{tabular}{lllll}
\hline Sessions & Top three & Top three medals total and proportion $(\%)$ & Others & Others medals total and proportion $(\%)$ \\
\hline The $25^{\text {th }}$ & CIS, USA, Germany & $302 ; 0.37$ & 61 & $513 ; 0.63$ \\
The $26^{\text {th }}$ & USA, Russia, Germany & $229 ; 0.27$ & 76 & $613 ; 0.73$ \\
The $27^{\text {th }}$ & USA, Russia, China & $244 ; 0.26$ & 77 & $683 ; 0.74$ \\
The $28^{\text {th }}$ & USA, China, Russia & $258 ; 0.28$ & 84 & $671 ; 0.72$ \\
The $29^{\text {th }}$ & China, USA, Russia & $282 ; 0.29$ & 108 & $676 ; 0.71$ \\
The $30^{\text {th }}$ & USA, China, Britain & $257 ; 0.27$ & 85 & $705 ; 0.73$ \\
The $31^{\text {st }}$ & USA, Britain, China & $257 ; 0.26$ & 84 & $716 ; 0.74$ \\
\hline
\end{tabular}

Note The data comes from the official website of China Olympic Committee: http://www.olympic.cn/ 
Table 5 The top 10 Countries' Advantage project in last 7 summer olympic games

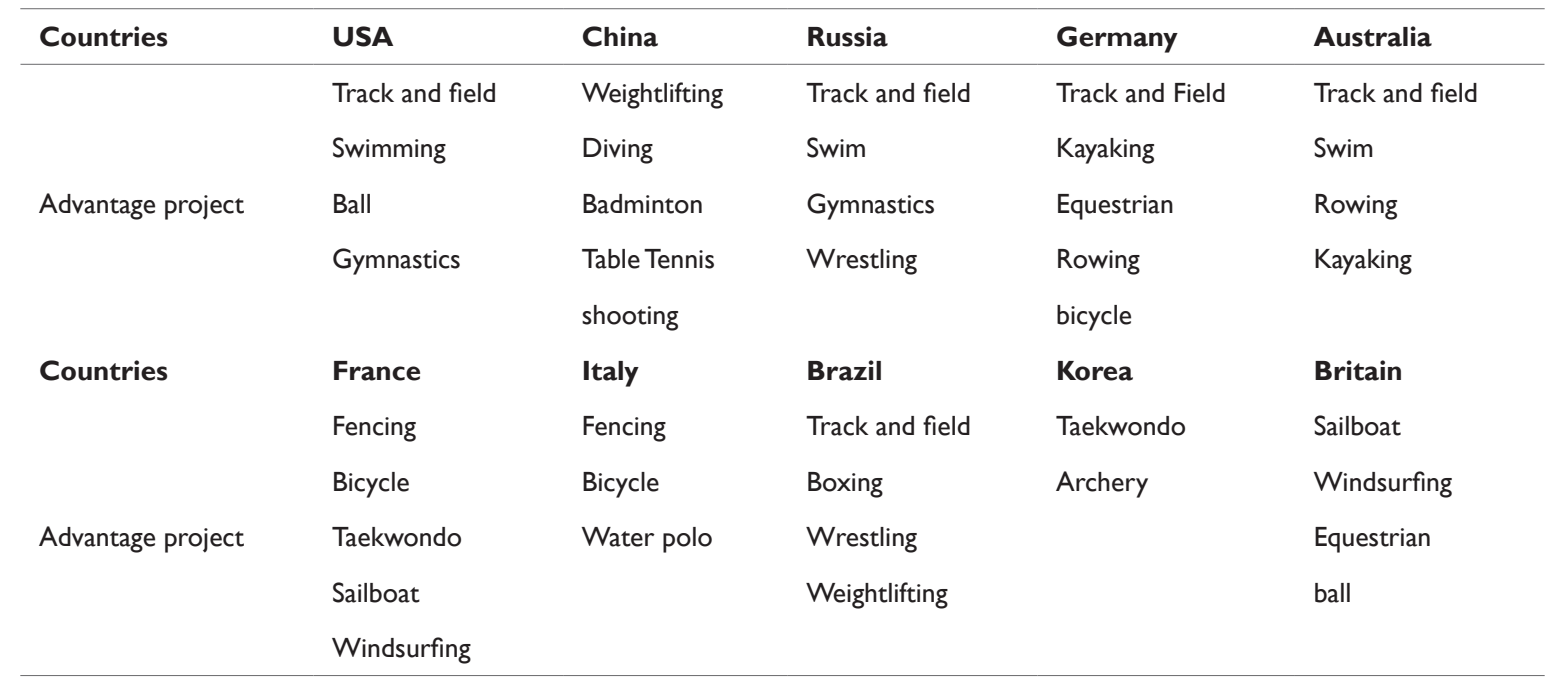

Note The data comes from the official website of China Olympic Committee: http://www.olympic.cn/

\section{The cross-culture of ideological system}

The Olympic ideological system mainly includes the Olympics, the Olympic purpose, the Olympic movement purpose, the Olympic spirit, the motto, the famous sayings and the others. ${ }^{17}$ It can be seen from table 6 that we can sum up Olympic ideological system in 4

Table 6 The epitome of main content of Olympic ideological system words "harmony, education, fairness and development". Which is all country and nations' pursuit, is the common ideal and goal? Therefore, the Olympic ideological system represents the common aspiration of the people all over the world, and is the basis for the fusion of cultures around the world.

\begin{tabular}{|c|c|c|}
\hline Directions & Contents & Contents epitome \\
\hline Olympism & $\begin{array}{l}\text { Olympism is a philosophy of life which strengthens the constitution, will and spirit, and makes it develop } \\
\text { in an all-round and balanced way. Seeking to integrate sport with culture and education, to create a way } \\
\text { of life based on the principle of striving for joy, playing a good example of education and respecting the } \\
\text { basic principles of social morality. }\end{array}$ & $\begin{array}{l}\text { Harmony, Education, } \\
\text { Fairness }\end{array}$ \\
\hline Olympic purposes & $\begin{array}{l}\text { A sport serves for the harmonious development of human beings, and promotes the establishment of a } \\
\text { peaceful society to safeguard human dignity. }\end{array}$ & Harmony, \\
\hline $\begin{array}{l}\text { Olympic movement } \\
\text { purposes }\end{array}$ & $\begin{array}{l}\text { The youth should be educated By carrying out sports activities without any form of discrimination and in } \\
\text { accordance with the spirit of the Olympics-mutual understanding, friendship, solidarity and fair play which } \\
\text { will establish a peaceful and better world. }\end{array}$ & $\begin{array}{l}\text { Harmony, Education, } \\
\text { Fairness }\end{array}$ \\
\hline Olympic spirits & Mutual understanding, friendship, solidarity and fair play & Harmony, Fairness, \\
\hline Mottos & Faster, higher, stronger & Development \\
\hline Sayings & Participation is more important than winning & Harmony, Education \\
\hline
\end{tabular}

Note Olympic ideological system comes from Kong Fanmin, Olympic Cultural Studies [M]. People’s sports press 2005:2I-22.

Research on the reason of Olympic internationalization success from the cross-cultural perspective

Cross-cultural organization management made the Olympics lead the healthy development of world sports: From the moment when the modern Olympics came out of Greece, history paid his glorious duty that is to lead the healthy development of world sports. A crosscultural international organization is the premise of the healthy development of international sports, a set of international rules system is the foundation of its healthy development. ${ }^{18}$ According to the Olympic Chart the IOC is mainly responsible for correctly guiding the development of competitive sports and ensure the Olympics regularly carried out, the main task of the NOC is to develop and maintain the Olympics in their respective countries or regions, The IFS is to take charge of the technical and administrative aspects of the sports events under its jurisdiction. ${ }^{19}$ The cooperation and complement each other of this three organizations make the Olympics (including other competitive sports) healthy develop in the world. Although there are stimulants, political interference and other negative effects, but once every 4 years the summer Olympics, the winter Olympics ,Paralympics and the Youth Olympics are orderly carried out under the organization of IOC. In addition to the Olympics, All kinds of sports competitions on every continent are becoming more active. This is inseparable from the rational plan and organization of the IOC and NOC, the coordination and standardization of the IFS as well. 


\section{The cross-cultural ideological system made the Olympic movement have a broad national foundation}

The success of the Olympics includes at least three aspects:

i. The overwhelming majority of countries in the world actively participate in it;

ii. It leads the development of international sports;

iii. The most extensive mass base. The development of these three aspects cannot be separated from the soul of the Olympics, that is, the ideological system.

The Olympic ideological system mainly includes Olympism, the Olympic purpose, the purpose of the Olympics, the Olympic spirit, motto, famous sayings and others, ${ }^{20}$ as mentioned earlier, we can use "harmony, education, fairness, development" 4 words to summarize it. The Olympic ideological system has been practiced all over the world since it was founded, such as:

I. Emphasis on education. Education and Culture Committee was established. The Youth Olympics was set up to integrate sport with culture and education that the youth are educated in accordance with the Olympic spirit- mutual understanding, friendship, solidarity and fair play.

II. Care about the growth of the disabled. The Paralympics was set up to call on the world to encourage, care for and help the disabled.

III. Concerned about the development of youth in poor countries.

The Olympic Solidarity Fund was set up to help some NOC to carry out their national sports and education undertakings. For example, in December 8, 2014, the IOC passed the Olympic 40 reforms, the 19th of Olympic Channel establishment plan and the 24th of hope project construction, mainly for the different cultures and different nationalities adolescents around world that their sports and culture education were strengthened. The Olympic ideology which was expressed by IOC with Olympic Charter is actually every government and people's common aspiration and desire. And was unremittingly taken actions by IOC with people all over the world in more than 100 years of development, which makes it have a world wide support and participation.

\section{Cross-Cultural exchanges and exhibition made various national cultures respected and developed}

Since the development of human society, colorful and splendid cultures were created. In a large scale, there are eastern culture and Western culture, from the countries and the nations, there are Chinese culture, India culture, Mayan culture, and so on. These cultures are the wisdom crystallization of the working people of the countries and the nations. The Olympic culture is a multi-cultural, ${ }^{21-23}$ which is the main component of sports culture. From the broad sense, sports events such as basketball and volleyball, sports venues and equipments, sports training concepts, sports management systems all belong to sports culture. It is precisely because of these differences, each country and nation create different sports cultural characteristics, such as Chinese sports events advantages, the characteristics of Chinese sports training methods, the characteristics of Chinese sports technique and tactics, Chinese sports " Nationwide system ", and so on. This is not only the wealth of the Chinese people, but also the common wealth of the world people. It should be respected and shared by people all over the world. The Olympics bears this important responsibility and provides this platform for the people of the world.

The Olympics is also a platform for world cultural exchange. ${ }^{24}$ Due to the influence of geography, climate and politics, the sports culture of different countries are very different, which is the premise of sports culture exchange. ${ }^{25}$ Numerous historical facts have proved that the speed and level of culture development depend on its collision, communication and integration with other cultures, and depend on the richness of cultural resources it can utilize. The more diverse and richer the cultural resources are, the faster and healthier the culture develops. The Olympics displays each national culture, at the same time, also gives each other a chance to communicate, so that each national culture absorbs nutrients from each other, and get richer and more developed.

\section{Conclusion}

The International Development of modern Olympics is very successful.1) the organization includes most of the world's countries and major sports associations. The number of the NOC has increased from 8 in 1900 to 2014 in 2012 London Olympics, IFS has developed to $64 ; 2)$ The Olympic scale is becoming bigger and bigger. The Summer Olympics lasted more than half a month, the participating athletes reached more than 10000; The number of audiences watching the opening and closing ceremonies through the TV broke the record many times. The total economy was huge, such as the Beijing Olympics, more than 5 billion audiences from more than 220 countries and regions watched the games, total economy reached a record about one hundred and twenty billion Yuan, not included all pick match in each continent; 3) sports have become increasingly active. In addition to the summer Olympics, the other Olympic Games have also had an unprecedented development, the Winter Olympics, the Paralympics, the Youth Olympics; many related cultural and scientific activities are being carried out worldwide. From the cultural perspective, the modern Olympics have Cross-cultural features in 4 aspects: the organization and organization members, bidding and hosting, sports projects and ideological system. Which precisely are the reasons for the great success of the Olympics internationalization? With the development and progress of the society, the Olympic crossculture will be further strengthened and the internationalization of the Olympics will be more successful.

\section{Acknowledgements}

None.

\section{Conflict of interest}

Authors declare that there is no conflict of interest.

\section{References}

1. Kong Fanmin. The study of Olympic culture. J Sports and science. $2003 ; 1: 20-22$

2. Xiong Douyin. Research on Olympic culture. Journal of physical education. 2005;1:11-14

3. Kong Fanmin. On the integration, connotation and innovation of the Olympic culture. J Sports culture Guide. 2005;5:27-30.

4. Gao Fenghua. The significances of the Olympics globalization. Sports and scientific research. 2006;23(2):23-24. 
5. Ren Hai, Sun Baoli, Zheng Bin, et al. Olympic movement [M]. Beijing: People's Sports Press. 2005.

6. Ru Xiuying, Zhou Jianmei. IOC analysis of tissue properties [J]. Journal of Xi'an Physical Education University. 2004;(21)5:1-3.

7. Official website of the Chinese Olympic Committee, China.

8. Luo Jianzhang. Analysis of agenda 2020. J Sports culture Guide. $2015 ;(6): 1-4$.

9. Zhang Haijun, Zhang Haili, Guo Xiaotao. On the Development of Brazil Football and Volleyball. J Sports \& science. 2011;32(1):94-97.

10. Li Ouyan. Investigation of Argentina sports. J sports Culture and history. 1997;(9):46-48.

11. Wang Haibin. Comparative study on the teaching philosophy of excellent fencing coaches in France and China-material selection and training. Journal of Beijing Sports University. 2009;32(3):49-52.

12. Cui Minji. A Comparative Study on the Development of Taekwondo in Some Middle Schools in China and South Korea [D] Hunan Normal University. 2014. p. 1-5.

13. Fang Xiaowei, Feng Tao. Research on Korean Archery Reserve Talents. Journal of Chengdu Sports University. 2014;40(2):60-64.

14. Chen Jiansheng. Korea National Technology-Archery. Today's middle school students. 2010;(3):40-41.

15. Hu Bingyang. Characteristics and Enlightenment of Australian competitive sports talent training. Adolescents sports. 2016;43(11):138-140.
16. Zhang Haijun, Zhang Haili. British sports and the London Olympic Games [J]. Sports culture Guide. 2009;(5):151-155.

17. Kong Fanmin. Research on Olympic culture [M]. Beijing: People's Sports Press. 2005. p. 21-22.

18. Zhang Haijun, Zhang Haili, Guo Xiaotao. The reason of Olympics successful internationalization [J]. Sports culture guide. 2010;7:139-142.

19. Ren Hai. Olympic Sports reader [M]. Beijing: People's Sports Press. 2005. p. 147-161.

20. Kong Fanmin. Research on Olympic culture [M]. Beijing: People's Sports Press. 2005. p. 21-24.

21. Cui Lequan. On the Olympic culture [J]. Sports culture Guide. 2009;9:140-144.

22. Zhang Liyan. The development of Olympic culture from the perspective of cultural identity [D]. Shandong Normal University. 2015;5:1-4.

23. Zhou Lihua. On the Olympic cultural characteristics and development. Sports culture Guide. 2004;(7):23-24.

24. Li Yanan. Study on cross-cultural communication of Olympic culture. Journal of Shangqiu Normal University. 2010;26(11):28-31.

25. Lu Yuanzhen. The identity and mutual complementary of Chinese and western sports culture. Journal of Jilin Institute of Physical Education. $2013 ;(29) 1: 8-24$. 